\title{
Peningkatan Kapasitas Manajemen Kesekretariatan Pengurus OSIS Berbasis Studi Kasus di SMAN 1 Pariangan Tanah Datar
}

\author{
Jendriadi $^{1}$, Adriantoni ${ }^{2}$, Ismira ${ }^{3}$ Warlan Sukandar ${ }^{4}$ Alfiyandri $^{5}$ Lisa Yuniarti $^{6}$ \\ 1,2,3,4,5,6 Universitas Adzkia, Indonesia \\ E-mail: jendriadi@stkipadzkia.ac.id
}

2021 by the authors. Submitted for possible open access publication under the terms and conditions of the Creative Commons Attribution-ShareAlike 4.0 International License-(CC-BY-SA) (https://creativecommons.org/licenses/by-sa/4.0/)

do) DOI: $\underline{\text { http://dx.doi.org/10.30983/dedikasia.vlil.4880 }}$

\begin{tabular}{ll}
\hline \multicolumn{2}{l}{ ARTICLE INFO } \\
\hline Submit $\quad: 20$ Januari 2021 \\
Revised $\quad: 14$ April 2021 \\
Accepted $:$ 30 Juni 2021
\end{tabular}

\section{Keywords:}

Peningkatan, manajemen kesekretariatan, OSIS

International License-(CC-BY-SA)

(https://creativecommons.org/licenses/by-sa/4.0/)

do) $h$ ttp:://dx.doi.org/10.30983/dedikasia.vlil.4880

\begin{abstract}
Dalam berorganisasi, ilmu manejemen sangat dibutuhkan bagi pengurus yang akan menjalankan roda organisasi. Hal itu disebabkan kesuksesan suatu organisasi didukung oleh sejauh mana kapasitas pimpinanan dan anggota dalam mengatur organisasi yang dikelolalnya. Sebenarnya, dalam ilmu manejemen terdapat beberapa fungsi pengelolaan yang mesti diterapkan, yaitu fungsi planning (merencanakan), fungsi organizing (pengorganisasian), fungsi directing (menggerakan) dan fungsi controling (pengawasan). Dalam pelaksanannya, empat fungsi manajemen ini sangat dibutuhkan sehingga dengan menjalankan empat fungsi manajemen tersebut maka apa yang menjadi tujuan organisasi akan dapat tercapai. Terkhusus kapasitas kesekretariatan, memegang peran penting dalam menata berbagai administrasi dalam organisasi OSIS serta surat menyurat yang diperlukan. Metode pelaksanaan kegiatan ini berupa tanya jawab dan studi kasus sehingga tidak terjadi kebosanan di kalangan peserta pelatihan.
\end{abstract}

This is an open access article under the CC-BY-SA license

\section{Pendahuluan}

Suatu hal yang tidak bisa dipungkiri bahwa sekolah merupakan jadi salah satu tempat di mana masalah sosial kerap terjadi. Bolos alias tidak masuk kelas secara sengaja, huru-hara tidak jelas, tawuran, narkoba dan bebrbagai kenakalan lainnya. Di satu sisi sebenarnya siswa SMA mestilah menikmati masa-masa indah di sekolah dengan mengukir berbagai prestasi yang dapat membanggakan dirinya dan orang terkasih. Salah satunya adalah dengan mengukir prestasi gemilang sebagai modal menghadapi masa depan yang jauh lebih baik dari hari ini. Masa-masa sekolah merupakan masa yang paling berharga dan begitu indah. Tidak heran jika ada ungkapan lagu yang populer pada masanya "Tiada masa paling indah, masa-masa di sekolah". Maka, masa-masa indah yang tercipta di masa sekolah semestinya diisi dengan kegiatan-kegiatan positf serta bernilai guna.

Untuk mengatasi kondisi yang kurang mengenakan dari siswa tentunya mesti ada solusi dari sekolah dengan mengambil beberapa tindakan. Beberapa permasalahan tersebut diantaranya adalah : Perselisihan, merusak fasilitas sekolah, tidak menghormati warga sekolah, Bullying, dan lain sebagainya. Masalah sosial di lingkungan sekolah adalah situasi yang harus dihadapi setiap hari oleh pihak sekolah. Maka dari itu, berbagai langkah antisipasi harus disiapkan demi menjamin kelancaran 
proses belajar dan mengajar. Dengan cara selalu berusaha untuk meminimalisir timbulnya masalah dengan melakukan tindakan preventif yang sesuai dengan prosedur sekolah maupun lembaga.

Salah satu upaya yang mesti dilakukan adalah dengan melakukan kegiatan yang positif sambil menggali berbagai potensi yang dimiliki oleh siswa. Hari-hari siswa disibukkan dengan berbagai kompetisi serta pelatihan yang menyenangkan. pihak sekolah tentu berkewajiban memberikan wadah bagi siswa yang ingin mengembangkan talenta, minat, dan bakatnya. Salah satu upaya yang dapat dilakukan oleh sekolah adalah dengan melakukan kegitan pelatihan peningkatan kapasitas manajemen kesekretariatan pengurus OSIS. Selain itu, tidak dapat dipungkiri bahwa perguruan tinggi sebagai sumber ilmu pengetahuan dan teknologi, bukanlah menara gading di tengah arus pembangunan, tetapi harus mampu mengembangkan diri sebagai bagian integral dari proses pembangunan itu sendiri. Dengan demikian, sesuatu yang sudah semestinya STKIP Adzkia mengadakan pelatihan pengelolaan manajemen kesekretariatan berbasis studi kasus di SMAN 1 Pariangan Kabupaten Tanah Datar.

Adapun tujuan dari kegiatan pengabdian ini adalah untuk memberikan pembekalan kepada siswa secara umum dan pengurus OSIS di SMAN 1 Pariangan secara khusus dalam menghadapi pergantian kepemimpinan pada tahun ajaran 2021/2022. Dengan adanya pembekalan ini, semua siswa memiliki wawsan yang mumpuni dalam mengelola serta menjalankan roda organisasi.

\section{Kajian Teori}

\section{Pelatihan dan Peningkatan Kapasitas Manajemen}

Manajemen Kapasitas merupakan sarana untuk menetapkan fungsi untuk mengukur, memantau, dan menyesuaikan batasan atau tingkatan dari kapasitas dalam tatanan untuk mengeksekusi dan melaksanakan jadwal kerja. Kapasitas manajemen dilaksanakan dengan menjadi pondasi berdasarkan eksekusi sebanyak 4 tingkatan yang menjadi dasar, yaitu :perencanaan kebutuhan sumber daya, perencanaan kapasitas "rough-cut" artinya dalam hal rasionalisasi ada pemotongan kasar yang memangkas kapasitas manajemen sumber daya secara umum, kemudian dari hasil tingkatan "roughcut"diatas menghasilkan "perencanaan kebutuhan kapasitas", setelah perencanaan kebutuhan kapasitas maka dapat dilakukan "kendali input / output". Latihan (training) dimaksudkan untuk memperbaiki penguasaan berbagai keterampilan dan teknik pelaksanaan kerja tertentu, terinci, dan rutin. Pelatihan (training) adalah sebuah proses di mana orang mendapatkan kapabilitas untuk membantu pencapaian tujuan-tujuan organisasional. Adapun Adrew E. Sikula (2020) mengemukakan bahwa pelatihan (training) adalah suatu proses pendidikan jangka pendek yang mempergunakan prosedur sistematis dan terorganisasi. Sedangkan Chris Landauer (1996) berpendapat bahwa pelatihan adalah sesuatu yang kita harap dapat menjadi bagian yang tidak 
terpisahkan dari pola pikir. Berdasarkan beberapa pengertian di atas bahwa pelatihan merupakan suatu proses perbaikan diri untuk mendapatkan suatu keterampilan maupun keahlian secara terprogram dan sistematis.

Secara umum, pelatihan merupakan pengembangan sumber daya manusia untuk sebuah organisasi atau perusahaan. Adapun dalam penelitian ini, pelatihan yang dimaksud bukan pelatihan dalam perusahaan atau organisasi tertentu, melainkan proses pelatihan dalam membentuk kepribadian peserta didik di lingkungan sekolah.

Dalam lingkungan sekolah pelatihan berlaku sebagai pengembangan keterampilan tertentu peserta didik. Pelatihan juga merupakan sebuah proses pendidikan, karena mempelajari dan melakukan proses perbaikan merupakan bagian dari pendidikan.

\section{Hakikat Organisasi Siswa Intra Sekolah (OSIS)}

Setiap sekolah pasti memiliki Organisasi Siswa Intra Sekolah atau yang biasa disingkat OSIS. Selain menjadi sebuah organisasi, OSIS juga memiliki banyak manfaat, baik bagi para pengurusnya, sekolah, maupun bagi siswa siswi lainnya. Berikut 10 manfaat OSIS yang harus diketahui: 1) Menjadi Wadah Kegiatan Yang Positif. Dengan adanya OSIS, para siswa-siswi sekolah memiliki sebuah wadah untuk mengisi waktu luang kamu dengan kegiatan kegiatan yang positif. Dengan adanya OSIS bisa mencegah kamu dari pergaulan pergaulan kurang baik di luar sekolah. 2) Mengadakan Berbagai Kegiatan Seru. Dengan adanya OSIS, maka banyak kegiatan kegiatan seru dan menyenangkan yang bisa kamu adakan dan bermanfaat baik bagi sekolah maupun bagi para siswa-siswinya. 3) Sarana Komunikasi Antar Siswa OSIS juga bisa menjadi sarana komunikasi antara para siswa dan bisa menjadi wadah untuk menyampaikan aspirasi para siswa. OSIS bisa menjembatani komunikasi antara siswa-siswi dengan pihak sekolah. 4) Mengembangkan Berbagai Keterampilan. Manfaat OSIS selanjutnya adalah sebagai tempat untuk mengembangkan keterampilan keterampilan di luar pelajaran sekolah untuk para siswa-siswinya. 5) Melatih Kemampuan Berorganisasi. OSIS dapat melatih para pengurus serta siswa-siswi yang tergabung didalamnya untuk belajar berorganisasi dan bekerja sama dalam tim sejak dini. Kemampuan ini tentu akan dibutuhkan oleh para siswa siswi tersebut di masa depan. 6) Melatih Tanggung Jawab Para Siswa. Dengan adanya kegiatan OSIS, para siswa-siswi yang menjadi pengurus akan mendapatkan jabatan masing-masing dimana kamu akan berlatih bagaimana caranya bertanggung jawab terhadap kewajiban kamu. 7) Wadah Untuk Berkumpul Para Siswa. OSIS juga bisa menjadi suatu wadah untuk berkumpulnya para siswa dari kelas-kelas dan tingkatan yang berbeda. Ini bisa menambah kedekatan antar para siswa di sekolah tersebut. 8) Membuat Kegiatan Lebih Terorganisir. Dengan adanya OSIS dan pengurus pengurus, maka kegiatan-kegiatan yang ada di sekolah bisa terorganisir dengan baik karena adanya struktur kepengurusan OSIS yang menangani berbagai kegiatan tersebut. 9) Mewadahi Ekstrakulikuler 
Yang Lain. Setiap sekolah pasti memiliki beragam ekstrakulikuler yang berbeda beda dan disesuaikan dengan minat dan bakat para siswanya. Dengan adanya OSIS, ekstrakulikuler ekstrakulikuler ini bisa diwadahi dan diorganisir dengan lebih rapi di bawah OSIS. 10) Melatih Manajemen Waktu Para Siswa. OSIS bisa membuat para siswa yang menjadi pengurusnya belajar mengenai management waktu, antara membagi kegiatan sekolah dengan kegiatan yang ada di OSIS.

\section{Peranan Studi Kasus}

Berbagai metodologi dan metode diupayakan untuk mendapatkan hasil penelitian dan analisis yang akurat dan tidak memihak sehingga dapat dikembangkan lebih lanjut kedepannya. Ketika meneliti suatu ilmu pengetahuan adalah penting untuk memperhatikan metode dalam memlilih studi kasus yang tepat karena dapat digunakan dalam menganalisis data-data yang dikumpulkan. Penggunaan studi kasus sendiri tidak sepenuhnya dianggap sebagai upaya dalam membuat generalisasi terhadap data-data yang ditemukan dalam suatu fenomena untuk dianalisis lebih lanjut, karena ilmu sosial sendiri bersifat dinamis. Banyak ilmuwan melihat bahwa dengan mengangkat suatu studi kasus maka mengangkat suatu studi empirikal yang memang terjadi di lapangan yang sejatinya memiliki pola sendiri dalam menentukan metode yang akan dibangun. Pada pembahasan kali ini, penulis akan menjelaskan lebih lanjut terkait studi kasus dalam penelitian ilmiah, rasionalisasi penggunaannya, serta metode dalam menentukan studi kasus yang tepat.

Menurut Burton (2000) bahwa studi kasus adalah salah satu metode atau cara yang bisa digunakan ilmuwan ketika meneliti sebuah penelitian ilmiah yang tujuannya sebagai dasar dalam membangun serta menghimpun data-data yang ada. Studi kasus juga dapat dikatakan sebagai observasi terhadap sebuah fenomena yang terjadi terhadap individu, negara, atau penerapan suatu program tertentu. Studi kasus menurut Yin (2003) juga dikatakan sebagai cara yang digunakan dalam meneliti penelitian ilmiah selain penggunaan eksperimen, survey, telisik sejarah, serta pengumpulan informasi yang tepat dalam peneliti suatu penelitian ilmu sosial. Pengaplikasian dari studi kasus sendiri tergantung pada tipe rumusan masalah, skill peneliti dalam mengontrol kejadian behavioral yang sesungguhnya, serta usaha peneliti dalam fokusnya terhadap fenomena kontemporer sebagai lawan dari fenomena yang historis. Sehingga dapat dilihat bahwa studi kasus merupakan usaha ilmuwan dalam membangun generalisasi atau pemahaman umum terhadap realitas akan tetapi tidak secara khusus untuk membangun generalisasi.

Melihat definisi dari studi kasus yang sudah dijelaskan maka perlu dibedakan dengan studi empirikal mengingat kedua hal ini berasal dari fenomena yang terjadi pada realitas yang dianalisis dan berupaya ditemukan permasalahannya. Menurut Yin (2003) studi kasus sebenarnya adalah penelitian empiris yang menganalisis fenomena kontemporer dalam konteks realita, terutama ketika batasan antara fenomena dan konteks tidak dapat dibuktikan dengan jelas. Sehingga, dalam studi Hubungan Internasional menurut Hermann (2002) menyatakan bahwa beberapa teori yang ada lantas dibentuk 
untuk menjelaskan pola politik internasional yang mana teori serta studi kasus dikaitkan untuk menciptakan common ground bagi para penstudinya. Contohnya adalah teori rasionalis yang memandang fenomena perang yang empiris dapat digunakan sebagai patokan dalam mencari studi kasus, sehingga dapat dilihat bahwa studi kasus mampu menginvestigasi fenomena-fenomena terkini yang sedang terjadi akan tetapi fenomena dan konteksnya tidak jelas, sedangkan studi empiris melihat fenomena yang benar-benar terjadi (Burton, 2000).

Studi kasus memiliki peranan penting dalam meneliti ilmu sosial dimana penggunaan studi kasus adalah rasional dalam membuat generalisasi analitis, bukan kesimpulan statistikal (Yin, 2003). Penggunaan studi kasus juga berfungsi dalam memberikan penjelasan dan eksplanasi, deskripsi, ilustrasi, eksplorasi, serta evaluasi dimana rumusan masalah yang berbentuk how dan why terhadap suatu fenomena. Hal ini juga umumnya diguanakan ketika penelitian memiliki biaya yang rendah sehingga peneliti mampu menyelaraskan hipotesis yang mengandung proses eksplisit dari teori dengan kejadian yang benar-benar terjadi, sehingga menemukan non-event dan karakteristiknya, serta mampu dikombinasikan antara analisis eksplorasi dengan konfirmasi dalam desain penelitian. Menurut Maoz (2002) juga menyatakan bahwa studi kasus menjadi hal penting karena sumber daya dan biaya yang dibutuhkan tidaklah banyak, masalah yang ada meningkat lebih cepat, serta memiliki potensi terjadi penyimpangan-penyimpangan yang ada antara realitas dengan teori yang memungkinkan munculnya anomali.

Peneliti dalam menganalisis suatu studi kasus tidak memiliki kontrol behavioral atas fenomena yang terjadi, sehingga rasionalitas dalam meneliti pun menjadi penting. Menganalisis suatu fenomena melalui studi kasus, menurut Burton (2000) menjelaskan bahwa peneliti harus menentukan unit analisisnya, baik itu individu, kelompok, organisasi, atau unit analisis lainnya. Menentukan pendekatan yang digunakan pun kemudian penting untuk diperhatikan, seperti pendekatan sosiologi, psikologi, politik, atau pendekatan studi lain yang bisa dilanjutkan dalam menentukan batas dan perbandingan data. Pemilihan studi kasus akan lebih baik jika didasari dengan pemahaman dasar yang jelas dan tidak memihak dimana peneliti terkadang tidak memerhatikan ketika memberikan definisi permasalahan yang akan diteliti sehingga fokusnya tidak bisa mengerucut. Hal ini dikarenakan penggunaan studi kasus sendiri fungsinya adalah untuk menjelaskan suatu hal untuk dipelajari lebih mendalam, sehingga sebaiknya fokus dari penelitian semakin terinci dan mengerucut. Pemilihan studi kasus sendiri harus berdasar pada rumusan masalah yang akan dibahas dalam penelitian ilmu sosial, serta tidak memilih lebih dari satu studi kasus karena pada dasarnya terdapat batasan sumber daya, waktu, dan ruang bagi peneliti.

Proses dari penentuan studi kasus sudah melalui beberapa proses seperti yang sudah dipaparkan sebelumnya, akan tetapi hambatan tentu akan tetap hadir dalam memetakan penjelasan dari studi kasus. Hal ini kemudian karena dipengaruhi oleh tingkat kecerdasan, ego, serta aspek emosional peneliti dalam menganalisa suatu kasus. Hambatan yang ada bisa berasal dari prosedur pengambilan data, informan kunci, penelitian tingkat tinggi yang memerlukan pengamatan secara konsisten, serta 
presentasi dari data yang ditemukan (Burton, 2000). Penggunaan dari studi kasus sendiri juga pada umumnya berfungsi dalam penelitian kualitatif yang membawa peneliti kepada realitas akan tetapi tidak benar-benar membangun sebuah generalisasi. Seharusnya pembentukan dari studi kasus tidak hanya berfokus pada jenis pertanyaannya akan tetapi juga hubungan antar variabel yang disesuaikan dengan tujuannya masing-masing, yakni eksploratori, deskripsi, serta eksplanasi (Burton, 2000).

Berdasarkan pemaparan di atas dapat penulis simpulkan bahwa studi kasus adalah cara atau metode yang dapat digunakan peneliti dalam melakukan penelitian ilmiah selama kasus yang digunakan dapat digunakan sebagai bahan membangun dan mencari koleksi dan analisis data. Proses yang harus dilewati dalam memilih studi kasus yang tepat adalah peneliti harus menentukan unit analisis yang akan dianalisa, menentukan pendekatan yang akan digunakan, menentukan batas pembahasan dan waktu kasus yang akan diteliti, serta melakukan komparasi dengan data yang ada untuk menghindari penyimpangan dari studi terdahulu. Hambatan pun tidak lepas dalam meneliti studi kasus karena menyangkut tingkat intelegensi, serta tingkat emosional dari peneliti itu sendiri. Berbeda dengan studi kasus, studi empiris adalah ilmu yang hanya melihat fenomena-fenomena yang benar-benar terjadi, sedangkan studi kasus sendiri melihat suatu fenomena yang tidak jelas batasan fenomena dan konteksnya. Penulis berpendapat bahwa pengambilan studi kasus dalam meneliti suatu ilmu sosial adalah penting karena melalui studi kasus sendiri dapat memberikan penjelasan, deskripsi, ilustrasi, eksplorasi, serta evaluasi bagi para pembacanya dimana rumusan yang dibentuk dari how dan why terhadap suatu kejadian atau fenomena kontemporer menjadi acuan yang penting bagi peneliti itu sendiri.

\section{Metode}

Kegiatan pengabdian masyarakat dengan menggunakan metode penyuluhan dan pendampingan yang dilaksanakan di SMAN 1 Pariangan Kabupaten Tanah Datar Sumatera Barat pada hari Sabtu, 26 Juni 2021 Pukul 09.00-15.30 WIB di Ruang Serba Guna SMAN I Pariangan. Alasan pemilihan SMAN 1 Pariangan sebagai lokasi pengabdian dikarenakan SMAN 1 Pariangan memerlukan fasilitator yang akan mengarahkan siswa-siswi pengurus OSIS yang baru saja dilantik untuk mendapatkan pemahaman yang utuh berkaitan dengan kegiatan kesekretariatan beserta tugas pokok dan fungsinya.

Adapun siswa yang terlibat dalam kegiatan pelatihan ini berjumlah 60 orang yang meliputi pengurus OSIS dan perwakilan masing-masing kelas. Dalam kegiatan pelatihan, metode yang digunakan adalah studi kasus dan tanya jawab. Sehingga, kegiatan ini menjadikan siswa tetap semangat dan tidak bosan dalam kegiatan ini. Selain itu, adanya beberapa door prize yang diberikan kepada peserta membuat mereka mejadi semakin serius mengikuti kegiatan ini. 


\section{Hasil}

Kegiatan ini berorientasi menciptakan generasi muda yang memiliki jiwa dan semangat kepemimpinan yang baik dimulai semenjak mengenyam pendidikan di Sekolah Menengah Atas dengan harapan mampu menularkan jiwa kepemimpinan tersebut kapanpun dan dimanapun mereka berada.

Agar kegiatan pengabdian berjalan dengan baik,lancar dan maksimal, tim pengabdian mempersiapkan berbagai media dan peralatan yang ikut mendukung terlaksananya kegiatan pengabdian. Adapun peralatan yang diperlukan dalam kegiatan pelatihan ini adalah kertas HVS, Sound System, Infocus, laptop dan media lainnya yang ikut mensukseskan jalannya acara. Untuk lebih jelasnya, tahapan-tahapan dalam kegiatan pelatihan dapat dirinci sebagai berikut:

\section{Tahapan Persipan}

a. Peserta

Dalam mempersiapkan peserta yang akan berpartisipasi aktif dalam kegiatan pelatihan kesekretariatan, tim pengabdian berupaya menjalin kerjsama dengan pihak sekolah serta menyampaikan serangkaian kegiatan peserta diinformasikan oleh kepala sekolah dan wakil kepala bidang kesiswaan. Semua peserta sudah siap dan dapat dipastikan hingga dua hari sebelum berlangsungnya acara. Sebelum acara dimulai, diawali berfoto bersama dengan kepala sekolah dan wakil kepala bidang kesiswaan.

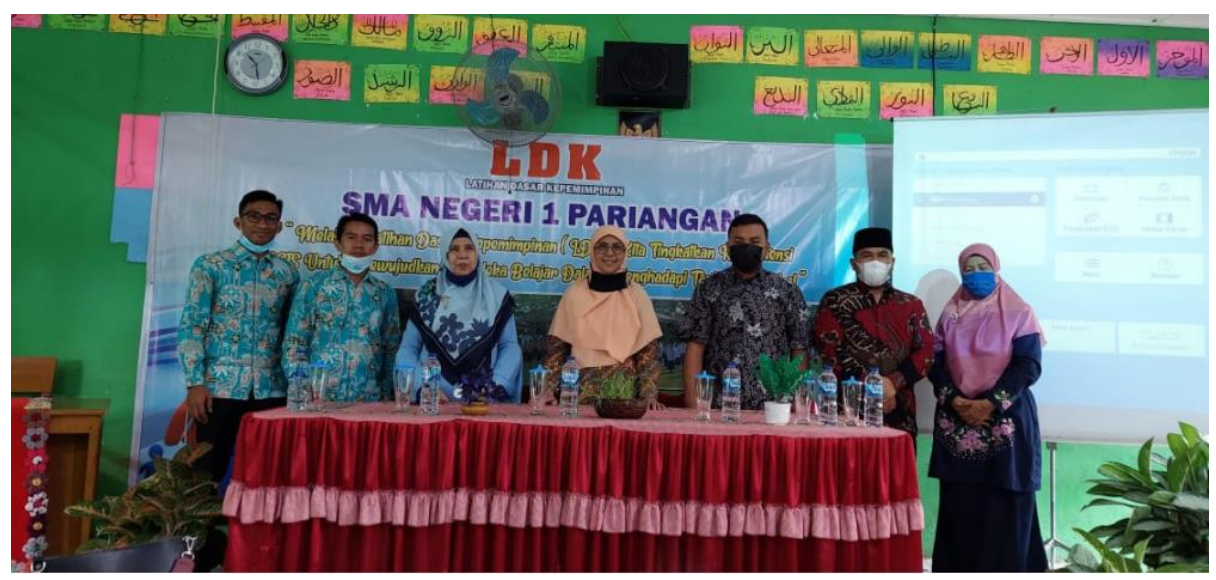

Gambar 1: Berfoto Bersama dengan Guru dan Wakil Kepala Sekolah Saat Kegiatan Pembukaan Pelatihan

b. Tempat

Berkaitan dengan persiapan tempat juga dapat dipastikan dengan komunikasi bersama kepala sekolah. Kepala sekolah telah mempersiapkan keperluan tempat dan berbagai peralatan lainnya yang dibutuhkan sebelum hari H. Selanjutnya, sekolah memutuskan untuk tempat kegiatan pengabdian dilaksanakan di ruang serba guna SMAN 1 Pariangan Kabupaten Tanah Datar. 


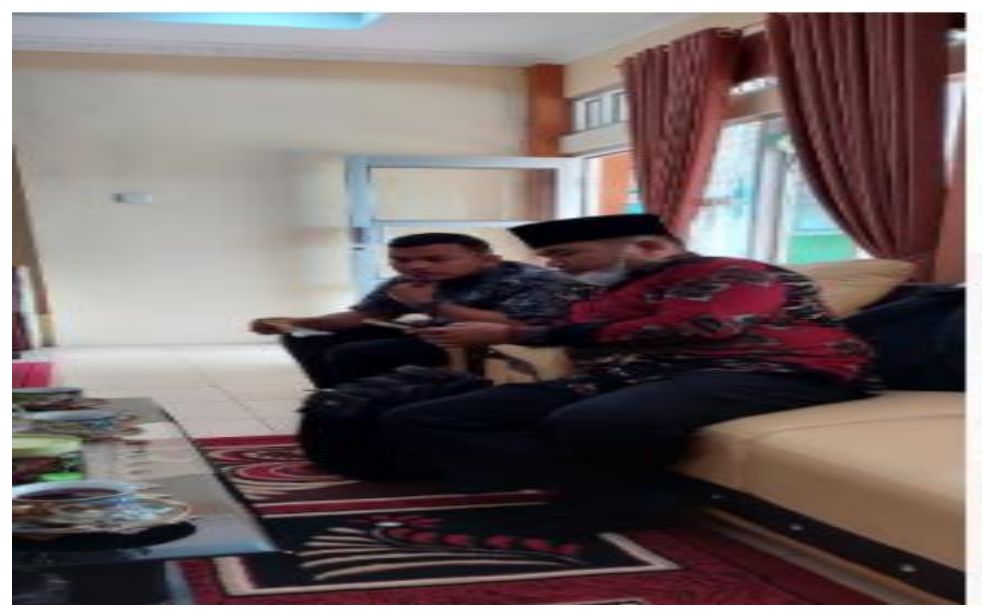

Gambar 2: Pengkondisian Tempat Pengabdian

c. Media

Secara etimologi "media" berasal dari bahasa Latin "medium" yang berarti "perantara" atau "pengantar". Lebih lanjut, media merupakan sarana penyalur pesan atau informasi belajar yang hendak disampaikan oleh sumber pesan kepada sasaran atau penerima pesan tersebut. Penggunaan media pengajaran dapat membantu pencapaian keberhasilan belajar (Priyanto, 2009). Pengertian yang serupa juga dikemukakan oleh Syafruddin, kata media berasal dari bahasa latin "medius" yang berarti tengah, perantara atau pengantar. Dalam bahasa Arab, media diartikan perantara atau pengantar pesan dari pengirim kepada penerima pesan. Media pembelajaran adalah alat bantu dalam proses belajar mengajar (Syaffruddin Nurdin, 2016). Adapun dalam kegiatan pengabdian ini, media yang menjadi andalan dalam kegiatan pelatihan ini adalah infokus, laptop, sound system, dan smart phone. Semua media tersebut menjadi salah satu sarana yang ikut mensukseskan jalannya sebuah pengabdian.

2. Tahapan Pelatihan

a. Studi kasus

Sebelum penyampaian materi diberikan studi kasus berupa permasalahan sederhana yang dihadapi oleh peserta dalam kehidupan sehari-hari. Saat memberikan materi studi kasus, peserta diminta tanggapan mereka terkait sebuah kunci yang ditemui di perjalanan, menghadap kemanakah kunci tersebut menurut persepsi mereka? Semua menjawab dengan jawaban yang bervariasi. Dari jawaban siswa semakin tergambar bagimana mereka mampu dalam melakukan manajemen terkhusus manajemen kesekretariatan. 


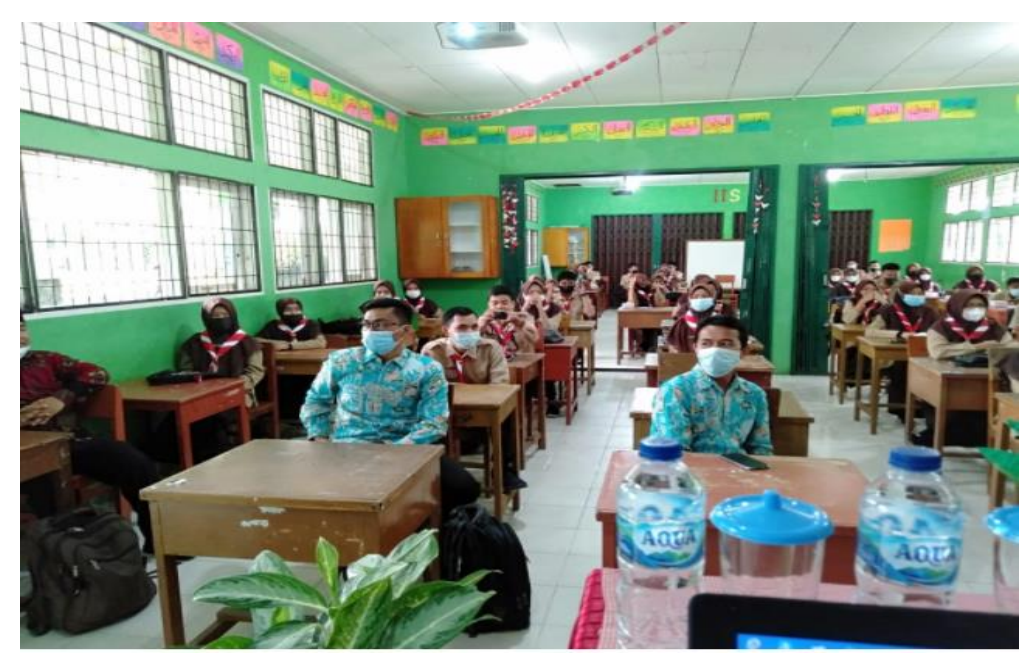

Gambar 3: Kegiatan Studi Kasus bersama Peserta

b. Penyampaian Materi Presentasi

Penyampaian materi presentasi dilakukan dengan memaparkan materi secara tanya jawab. Tidak sedikit yang langsung ada aktivitas tanya jawab bersama peserta pelatihan sehingga suasananya terasa begitu hidup.

c. Kuis

Sebagai upaya menjaga konsentrasi peserta pelatihan, disela-sela materi yang disampaikan diselipkan juga kuis-kuis yang menghibur dan menyenangkan peserta pelatihan.

d. Games

Games dalam kegiatan ini maksudnya adalah berupa kegiatan yang dimainkan hanya dengan memilih jawaban yang benar dari beberapa pilihan jawaban. Biasanya pertanyaan yang diberikan memiliki topik tertentu, tetapi ada yang topiknya beragam. Menurut Bentar (2011) quiz game adalah bentuk permainan atau pikiran di mana pemain (sebagai individu atau dalam tim) berusaha untuk menjawab pertanyaan dengan benar.

\section{e. Penutup}

Kegiatan peelatihan yang menyenangkan bagi peserta tidak terasa sampai pada ujung kegiatan. Namun semangat untuk menjadi pemimpin yang profesional dan berprestasi di kepungurusan OSIS masih membahana dan menggema di seantaro kelas. Kegiatan pelatihan diakhiri dengan pemberian doorprize serta berfoto bersama dengan semua peserta pelatihan.

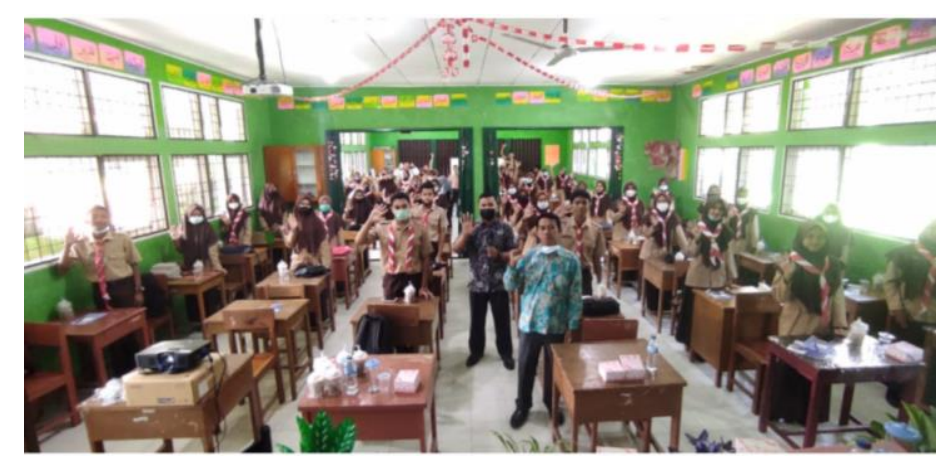




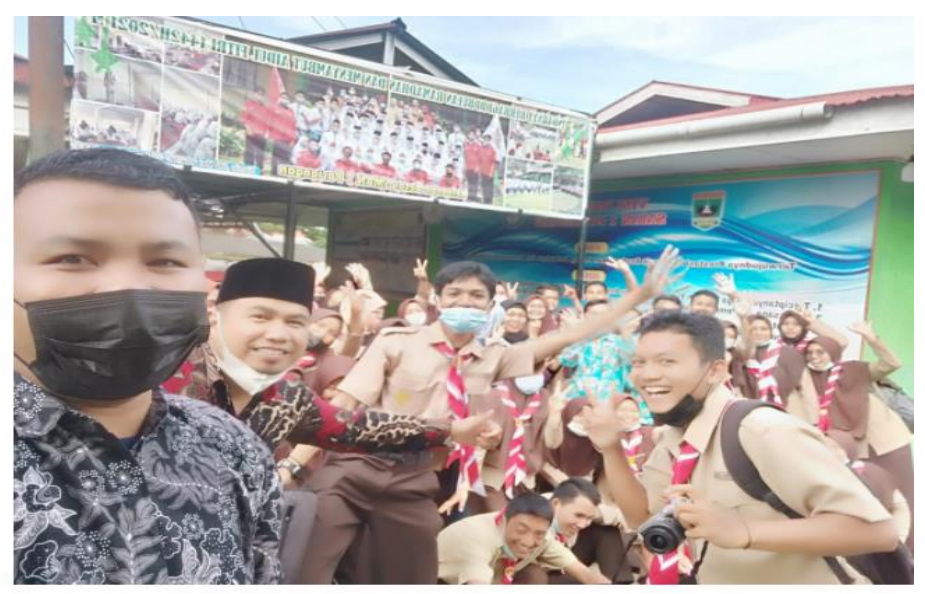

Gambar 4 dan 5: Foto Bersama dengan Peserta Pelatihan

\section{Tahapan Evaluasi}

Tahap evaluasi diakukan dengan cara mengamati berbagai perubahan kemampuan yang dimiliki oleh peserta dalam rangka pemahaman mereka terhadap kemampuan manajerial organisasi kesekretariatan. Baik pemahaman terhadap pengelolaan dan pengadministrasian berbagai dokumen yang ada di organisasi OSIS maupun dalam pembuatan surat menyurat.

\section{Pembahasan}

Berkaitan dengan kegiatan pelatihan peningkatan kapasitas kepemimpinan dengan berbagai metode sebenarnya sudah dilakukan oleh berbagai peneliti terdahulu. Seperti yang telah dilakukan oleh Jerusalem dkk (2018), tujuan pelatihan ini untuk meningkatkan kapasitas pimpinan sekolah dari sisi kepemimpinan sehingga mampu meningkatkan partisipasi dan komitmen guru dalam regenerasi kepemimpinan sekolah; serta meningkatkan kapasitas pimpinan sekolah dari sisi manajerial sehingga mampu meningkatkan pengelolaan sekolah yang berkualitas, efektif, dan efisien. Penekanan pada pelatihan ini adalah pada elemen kepemimpinan dan manajerial. Adapun pada kegiatan pelatihan kesekretariatan berbasis studi kasus di SMAN 1 Pariangan Kabupaten Tanah Datar sumatera Barat telah mampu membangkitkan semangat para siswa untuk bisa lebih professional dalam pengelolaan manajerial organisasi. Melalui berbagai studi kasus yang disampaikan oleh narasumber, peserta terlihat antusias dan semangat dalam mengikuti kegiatan pelatihan. Pada umumnya kegiatan kesekretariatan meliputi: 1. Menyelenggarakan pembinaan ketatausahaan, khususnya yang berhubungan dengan pekerjaan surat menyurat yang meliputi pembuatan surat, penerimaan surat, pengolahan surat, pendistribusian surat dan sampai pada penyimpanan surat. 2. Menyelenggarakan tata hubungan, baik secara inter maupun estern. 3. Menyelenggarakan kepanitiaan rapat. 4. Menyelenggarakan kegiatan yang sifatnya rahasia. 5. Menyelenggarakan pengaturan penerimaan tamu/kunjungan. 6. Menyelenggarakan tugas bantuan lain yang bersifat menunjang pelaksanaan tugas pokok dan menyediakan fasilitas, terutama untuk mengkordinasikan pelaksanaan tugas pokok 
organisasi. Secara umum, aspek-aspek tersebut telah dipahami oleh semua peserta didik dan mendatangkan antusias dari semua peserta.

\section{Simpulan}

Berdasarkan hasil pelaksanaan kegiatan pengabdian masyarakat di SMAN 1 Pariangan Kabupaten Tanah Datar diperoleh informasi sebagai berikut:

1. Kegiatan pelatihan kesekretariatan mampu membangkitkan semangat dan motivasi pengurus OSIS dalam melakukan manajerial kepengurusan dan pengarsipan berbagai dokumen penting dalam organisasi melalui pendekatan studi kasus.

2. Kapasitas siswa dalam membuat surat menyurat menjadi semakin terasah.

3. Guru, kepala sekolah dan berbagai stake holder di SMAN 1 Parianga menjadi semakin bersemangat dalam mendukung dan mensukseskan program-program kepengurusan OSIS SMAN 1 Pariangan.

\section{Daftar Pustaka}

Antisipasi Berbagai Masalah Sosial di Lingkungan Sekolah. https://reginapacis-jkt.sch.id/masalah-sosial-dilingkungan-sekolah.html. diakses 07 Juli 2021.

Anwar Prabu Mangkunegara, Perencanaan dan Pengembangan Sumber Daya Manusia, (Bandung: Refika Aditama, 2006

Burton, Dawn. 2000. "The Use of Case Studies in Social Science Research", dalam Dawn Burton (ed.),

Carlsnaes, Thomas Risse, dan Beth A. Simmons, Handbook of International Relations. London: SAGE Publications.

Hani Handoko, Manajemen Personalia dan Sumber Daya Manusia, (Yogyakarta: BPFE, 1996)

Hermann, Richard K. 2002. "Linking Theory to Evidence in International Relations", dalam Walter

Maoz, Zeev. 2002. "Case Study Methodology in International Studies: From Story Telling to Hypothesis Testing”, dalam Frank P. Harvey \& Michael Brecher (ed.), Evaluating Methodology in International Studies. Ann Arbor: the University of Michigan Press.

Research Training for Social Scientist. London: SAGE Publications.

Nurdin, Syaffruddin. 2016. Kurikulum dan Pembelajaran, Jakarta: Rajawali Press.

Noviani. 2013. Pengembangan Media Pembelajaran Berbasis Games sebagai Pendukung Mata Pelajaran Teknologi Informasi dan Komunikasi Materi Operasi Dasar Komputer menggunakan Adobe Flash. Skripsi. Tidak diterbitkan. Yogyakarta: Universitas Neheri Yogyakarta.

Padil. 2018. Paradigma Baru Pengabdian kepada Masyarakat yang Berkelanjutan. Jurnal Pengabdian Masyarakat Multi Disiplin. http://jurnal.univrab.ac.id/ .

Robert L. Mathis dan John H. Jackson, Human Resource Management 'Manajemen Sumber Daya Manusia', (Jakarta: Salemba Empat, 2011),

Santi Pratiwi. 2016. Pelatihan Presentasi Ilmiah untuk Meningkatkan Daya Saing dalam Kompetisi Ilmiahbagi Anggota Ekstra Kurikuler Ilmiah Remaja di Kota Semarang. Jurnal Semar Vol. 5 No.l hlm.2.

Umrella, Samad. 2018. “Urgensi Media dalam Proses Pembelajaran” Jurnal IAIN Ambon. Vol. l (hlm.2). Yin, Robert K. 2003. "Introduction”, dalam Case Study Research. London: SAGE Publications. https:/christiangamas.net/manajemen-kapasitas/ 